Sequence Stratigraphy and Sedimentology of the Upper Jurassic Arab and Hith Formations, Abu Dhabi, United Arab Emirates

A. Al-Mansoori* (Abu Dhabi Company for Onshore Oil Operations) \& C. J. Strohmenger (ExxonMobil Research Qatar)

For abstract, PTO

No full paper available 


\title{
15171 Sequence stratigraphy and sedimentology of the Upper Jurassic Arab and Hith formations, Abu Dhabi, United Arab Emirates
}

\begin{abstract}
Abdulla Al-Mansoori (Abu Dhabi Company for Onshore Oil Operations <amansoori@adco.ae>) and Christian J. Strohmenger (ExxonMobil Research Qatar <christian.j.strohmenger@exxonmobil.com>)
\end{abstract}

The Kimmeridgian-Tithonian Arab and Hith formations are part of the highstand sequence set of a second-order supersequence, built by five third-order composite sequences: (1) J70 Sequence, Jubaila/ Arab-D; (2) J80 Sequence, Arab-C; (3) J90 Sequence, Arab-B; (4) J100 Sequence, Arab-A/Lower Asab Oolite; and (5) J105 Sequence, Upper Asab Oolite/Hith), bounded on top by sequence boundary J110_ SB. The J70 to J105 sequences belong to the highstand sequence set of the Upper Jurassic second-order supersequence and show progradation of the facies belts towards the east. Through time, the lagoon behind the barrier bar complex became increasingly evaporitic being dominated by salina-type deposits during Hith deposition (J105 Sequence).

The overall depositional environment envisaged for the Arab Formation is that of a barrier-shoal complex with open-marine, offshore sedimentation to the east and a protected, evaporitic, platform interior (lagoon) to the west. A barrier-shoal complex was developed along the platform margin and deposition was dominated by oolitic grainstones. Concomitant deposition of sabkha, tidal-flat, salina, and lagoonal sediments occurred westwards, and open-marine mudstones and wackestones were deposited eastwards of the barrier-shoal complex.

Reservoir quality is strongly controlled by the depositional environment and the lithofacies types. The best reservoir is present within grain-dominated lithofacies types of the barrier shoal complex. Relatively poor reservoir quality is characteristic of mud-dominated lithofacies types that occur in open-marine environments. In the platform interior, the dominantly dolomitized lithofacies types show quite good reservoir qualities within thin intercalated packstone to grainstone layers, interpreted as tidal-channel or washover deposits. During Hith time, the restriction of the platform interior increased, and predominantly salina-type, anhydrite-after-gypsum was deposited.

The focus of this study is on the depositional environment of the anhydrite sediments, as it is important to distinguish between salina-type (saltern) and sabkha-typeevaporites. In contrast to sabkha-type deposits, where evaporites form within the host rock (sediment-dominated: late highstand and lowstand systems tracts), salina-type deposits represent subaqueous evaporite precipitations (evaporite-dominated: late lowstand and transgressive systems tracts deposits). Distinguishing between the different anhydrite depositional environments is crucial for the correct sequence-stratigraphic interpretation of the Arab and Hith carbonate-evaporite successions. 